Article

\title{
Organizations' Management of the COVID-19 Pandemic: A Scoping Review of Business Articles
}

\author{
Olivier Boiral ${ }^{1}$, Marie-Christine Brotherton ${ }^{1, *}$, Léo Rivaud ${ }^{1}\left(\right.$ and Laurence Guillaumie ${ }^{2}$ \\ 1 Department of management, Faculty of Business Administration, Laval University, \\ Pavillon Palasis-Prince, 2325, rue de la Terrasse, Quebec City, QC G1V 0A6, Canada; \\ Olivier.Boiral@mng.ulaval.ca (O.B.); leo.rivaud.1@ulaval.ca (L.R.) \\ 2 Faculty of Nursing, Laval University, Pavillon Ferdinand-Vandry, 1050, avenue de la Médecine, \\ Quebec City, QC G1V 0A6, Canada; laurence.guillaumie@fsi.ulaval.ca \\ * Correspondence: marie-christine.brotherton.1@ulaval.ca
}

check for updates

Citation: Boiral, O.; Brotherton, M.-C.; Rivaud, L.; Guillaumie, L. Organizations' Management of the COVID-19 Pandemic: A Scoping Review of Business Articles. Sustainability 2021, 13, 3993. https://doi.org/10.3390/su13073993

Academic Editor: Ki-Hoon Lee

Received: 2 March 2021

Accepted: 1 April 2021

Published: 2 April 2021

Publisher's Note: MDPI stays neutral with regard to jurisdictional claims in published maps and institutional affiliations.

Copyright: (c) 2021 by the authors. Licensee MDPI, Basel, Switzerland. This article is an open access article distributed under the terms and conditions of the Creative Commons Attribution (CC BY) license (https:/ / creativecommons.org/licenses/by/ $4.0 /)$.

\begin{abstract}
The objective of this study was to analyze the early COVID-19 crisis management practices implemented in organizations based on a scoping review of relevant business articles published on this issue in newspapers and magazines between March and May 2020. In total, after applying inclusion and exclusion criteria on 2707 potentially relevant articles, 246 articles describing organizational initiatives to manage COVID-19 were selected and analyzed in detail. The results of this study highlight the opportunities and threats arising from the pandemic as well as the most innovative measures put in place, particularly in the areas of health, human resources management (HRM), work organization, social and environmental responsibility, and crisis management. The description of the main practices identified and their illustration through various examples show the importance of corporate sustainability in managing the pandemic and demonstrate the cross-cutting nature of this crisis, which affects most corporate functions simultaneously. This study also makes it possible to identify certain leaders' approaches that can be considered exemplary or, in contrast, that should be avoided, while highlighting the paradoxes and difficulties of assessing corporate social responsibility in times of crisis.
\end{abstract}

Keywords: COVID-19 pandemic; corporate sustainability; crisis management; best practices; scoping review

\section{Introduction}

The COVID-19 pandemic has created a crisis unprecedented in terms of scale and social, economic, and environmental implications [1]. The consequences of this crisis in the most affected countries are manifold and of unprecedented severity for most organizations. In addition to its human impacts, particularly for victims with severe symptoms and for overburdened health services, restriction policies and the halting of economic activities in most industrialized countries have led to an economic crisis whose severity is often compared to that of 1929 [2-4]. Furthermore, the pandemic has created an endemic situation of uncertainty and confusion about risks to employees, measures and best practices that organizations should adopt, stakeholder pressures, government shutdown and recovery plans (including assistance to the most affected companies), the potential for new waves of contamination, and lasting changes forecasted for consumer habits [5-7]. For organizations, these uncertainties are all the more difficult to manage because there are few in-depth studies on the subject and the information available is scarce, partial, and contradictory. In this context, business articles published in newspapers and magazines describing concrete and practical initiatives implemented in organizations appear to be one of the main sources of information for corporate leaders and other stakeholders alike. However, these articles are scattered and, taken individually, the examples presented are rarely in-depth or significant. The scoping review method appears to be a very relevant approach for synthesizing the 
most significant information on a little-studied subject by limiting the biases associated with the use of a single study or specific type of data [8,9]. This method can be defined as "a form of knowledge synthesis that addresses an exploratory research question aimed at mapping key concepts, types of evidence, and gaps in research related to a defined area or field by systematically searching, selecting, and synthesizing existing knowledge" ([10], p. 1292).

The objective of this study was to analyze the early COVID-19 crisis management practices implemented in organizations based on a scoping review of relevant business articles published on this issue in newspapers and magazines between March and May 2020.

This study is relevant for three main reasons. First, while the current crisis has placed the emphasis on the vulnerabilities of our societies and on the preventive measures to be adopted at the individual level, organizations and the workplace in general represent one of the main vectors for the transmission of diseases such as COVID-19, including during periods of reopening [11-13]. According to the International Labour Organization (ILO), more than half of the world's enterprises, or about 436 million organizations, operate in sectors (e.g., retail sale, vehicle repair, manufacturing, food services, entertainment, transport) that can be considered high-risk in terms of disease transmission and that may require temporary or prolonged halting of their activities [14]. The practices put in place by organizations during the pandemic are therefore essential to limiting the risk of COVID19 transmission from economic activities. Second, most organizations appear to have been very poorly prepared for the current crisis or to have demonstrated a low level of resilience to its impacts $[1,5,11]$. This article's focus on examples of practices that have been put in place can help corporate leaders to improve this resilience and to better manage the current crisis or future pandemic episodes. Third, in the face of the significant risks associated with the pandemic and its socio-economic implications, organizations have a moral duty to put in place appropriate measures to ensure their legitimacy, respond to institutional pressures, and protect the health of their stakeholders, including employees and clients $[15,16]$. However, whether their behavior is, in fact, effective in terms of social responsibility remains, at best, uncertain. This article therefore sheds new light on the practices organizations have concretely put in place, and on the behaviors considered responsible for organizational leaders as well as those to be avoided.

The rest of the article is structured as follows. First, the academic literature on organizations' consideration of COVID-19 is analyzed. Second, the scoping review methodology used in this study is explained. Third, the main results are presented regarding the characteristics of the articles analyzed, the types of practices observed, and the behaviors to adopt and to proscribe. Finally, the contributions and practical implications of this article are discussed.

\section{Managing an Unprecedented Sustainability Crisis}

\subsection{Responding to a Multifaceted and Unanticipated Crisis}

The COVID-19 pandemic represents a multifaceted crisis that affects the main dimensions of corporate sustainability, which can be defined as the balanced consideration of social, economic, and environmental issues through strengthening of the social responsibility of organizations to better meet the current and future expectations of stakeholders [17-19]. Thus, for organizations, the COVID-19 pandemic raises major social issues (e.g., risk of contamination, protection of employee and client health, health measures, layoffs), economic issues (e.g., reduction of activities, risk of bankruptcy, management of financial impacts, market evolution), and environmental issues (e.g., the role of habitat destruction and climate change in the emergence of zoonoses such as COVID-19, vulnerability of organizations to ecosystem disruption, possible effects of air pollution on the spread of the virus). It is difficult to address these interrelated issues in a substantial way without strengthening organizations' social responsibility. Moreover, the risks of contamination linked to company activities (e.g., production and distribution of products and services, business travel) call for corporate leaders to be accountable for preventing or limiting the 
spread of the virus [15]. Lastly, the COVID-19 crisis has created new expectations among stakeholders, including regarding organizations' proactive participation in collective efforts to fight the pandemic, their responsibility in preventing illness in certain particularly affected sectors and in limiting the rise of unemployment, and their resilience to a crisis likely to create numerous disruptions in the supply of essential goods and services $[15,20]$. In addition to these broader issues, the consideration of health questions is an integral part of organizations' sustainable development practices [21-26]. Indeed, health is explicitly covered by the 17 United Nations Sustainable Development Goals (SDG 3, Good Health and Well-Being), to which a growing number of organizations adhere [25,27]. The same is true of the main sustainability reporting standards, such as the Global Reporting Initiative (GRI), which requires organizations to disclose information on their health and safety practices $[26,28]$.

Despite the close links between corporate sustainability and COVID-19 crisis management, the way in which organizations deal with this crisis, including in their sustainability practices, has not yet been studied in depth in the literature. A few studies have mentioned the moral obligation for companies to proactively manage the crisis, and have shown its links with environmental, social, and governance (ESG) issues $[1,15,20,29]$. Some authors have compared the current pandemic to the climate crisis, highlighting in particular the lack of corporate preparedness for major and multifaceted disasters of this type [30-32]. This lack of preparedness is reflected in the disclosure practices of organizations, which tend to minimize or even ignore the risks of a pandemic despite scientists' recurring warnings of the seriousness and high probability of its occurrence [3,33]. For organizations to engage in the responsible consideration of the COVID-19 pandemic, they would be required to develop collaborations with various stakeholders (e.g., NGOs, government, other companies) and to privilege long-term over short-term objectives [34-36]. However, this general advice is rarely supported by substantial empirical evidence or concrete cases to illustrate the implications of the pandemic for organizations' social and environmental responsibility.

Some articles have also addressed business management within the pandemic from a broader perspective. These articles mention the heterogeneity of the issues at stake for businesses and the need to put in place differentiated measures according to the specific situation of each organization $[1,37]$. Moreover, some studies have analyzed the response to the crisis in specific sectors or contexts, including the airline industry, Chinese universities, and the Canadian banking sector [20,38,39]. Talbot and Ordonez-Ponce [20] developed a typology of the responses to COVID-19 based on corporate documents according to their degree of proactivity and showed that, in the majority of cases, the policies put in place to help stakeholders (i.e., clients and community) during the crisis remained relatively limited despite the considerable financial means of the organizations concerned. Other studies have highlighted the varying degree of corporate resilience during the crisis and have shown its implications in various areas, including the supply chain, work organization, and occupational health and safety management [37,40-43]. For example, the development of telework and the consequences of social distancing measures for organizations and workers are often mentioned [1,44-46]. The particular risks to certain categories of employees, the stigmatization of groups of individuals potentially carrying the disease, stress at work during the pandemic, and inequalities in the distribution of "decent work" are also mentioned [14,29,47-50].

Generally speaking, the emerging literature on organizations' management of COVID19 provides a better understanding of the complexity of this issue and the unprecedented challenges faced by organizations. However, despite the emergence of various research studies on the subject, the organizational practices actually in place are still largely unknown and are mainly discussed on the basis of advice or general considerations rather than empirical studies or concrete examples. 


\subsection{Identifying the Best Practices for Managing COVID-19 Inside Organizations}

Periods of crisis, extreme uncertainty, and serious threats to the future of organizations require these organizations to reconsider practices, acquire new capabilities, and implement innovative measures to meet the challenges of an environment that has become much more uncertain and volatile [51-54]. In this context, the identification of good practices that have been successfully implemented in other organizations can help leaders to better manage the crisis and make decisions that appear to have proven successful elsewhere [55-57]. While there are apparently no specific studies on the subject, various good organizational practices are mentioned in articles from very different disciplines. Surprisingly, most of the good organizational practices noted in the academic literature on COVID-19 come from articles outside the management field. These practices essentially revolve around four interdependent themes: risk identification, planning of organizational responses, human resources management, and the application of security measures recommended by various public organizations.

First, several studies underline the importance of properly identifying the economic and health risks related to the organization's activities [38,48,58-60]. For example, some studies have analyzed the high risk of contamination and approaches to deal with this in environments where social distancing is more difficult to apply, in particular hospitals, educational establishments, and meat processing plants $[38,48,59,60]$. Assessing the level of risk for different categories of employees is also considered an essential practice in order to safeguard the health of the most vulnerable individuals and to put in place measures tailored to each situation, including, where possible, telework [47,61-64].

Second, various documents, mainly from the medical community, briefly mention some relevant organizational measures, such as the establishment of a cross-functional crisis management team or a response team including representatives of the top management, employees, and stakeholders in order to identify the most urgent measures and support their implementation [65-68]. The development of various action plans (e.g., contingency plans, restructuring, telework development, business resumption) based on identified risks and crisis scenarios is also mentioned [65,69-71].

Third, the adaptation of human resources management (HRM) practices appears to be essential, particularly for organizations most exposed to the risk of contamination. The measures mentioned include the development of internal skills to manage the pandemic through staff training or the consultation and recruitment of health experts $[7,59,72]$. The lack of clear guidelines in some organizations and the need to communicate transparently with employees and other stakeholders is also highlighted [11,13,41,44,69]. Consultation with employees and consideration of their expressed needs (e.g., lack of protective equipment, identification of risks, training and information needs, return-to-work plans, inappropriate behavior) are considered essential in order to promote effective measures and reduce stress at work [11,73-75].

Lastly, various public bodies have developed guides to good practices in the workplace, including the World Health Organization, the European Agency for Safety and Health at Work, the Centers for Disease Control and Prevention, and various health research centers $[44,76]$. These guidelines are essentially based on the public health guidelines in place in most industrialized countries (e.g., rules for social distancing, washing hands, sanitizing potentially contaminated surfaces, wearing protective masks, isolating people at risk, and redesigning common areas).

In general, while the academic literature identifies a number of good practices that can be useful to organizations, references in this area are very scattered and therefore difficult to gather for the purpose of defining and implementing a coherent set of relevant actions. To our knowledge, almost no specific studies have been published on early organizational management for the pandemic, and most of the proposed practices are based either on general guidelines or on public health directives that are not necessarily tailored to the needs of corporate leaders. Lastly, in the absence of concrete cases or examples illustrating 
how these practices are implemented in the workplace, the proposed recommendations may appear theoretical.

However, many relevant examples on the issue have been published in the news, particularly in business articles published in newspapers and magazines that are widely distributed and have collected a great deal of field information on organizations' management of the pandemic (e.g., interviews with leaders, case presentations, criticism of certain decisions). Although various management studies are based on the systematic analysis, to varying degrees, of articles published in business journals [77-80], this approach has not, to our knowledge, been used to collect examples of organizational practices for managing major crises, such as the COVID-19 pandemic.

\section{Materials and Methods}

The aim of this study was to better understand how organizations reacted at the beginning of the COVID-19 pandemic and to identify best management practices. It answers the following research question: What are the impacts of the COVID-19 pandemic on organizations and what are the best practices used by organizations for the early response to the pandemic?

The objective of this study was to analyze the early COVID-19 crisis management practices implemented in organizations based on a scoping review of relevant business articles published on this issue in newspapers and magazines between March and May 2020. In contrast to the systematic review approach, a scoping review is deemed more appropriate to rapidly address broader topics from articles with diverse study designs, without assessing the quality of the included studies [81]. This approach is also particularly well suited to studying new phenomena and informing emerging practices [10,82,83].

This study follows the methodology developed by Arksey and O'Malley [81] which comprises five main steps: identifying the research question; identifying relevant articles; selecting relevant articles; charting the data; and collating, summarizing, and reporting the results. This methodology has been adapted to be used for the study of business articles.

\subsection{Identifying Relevant Articles}

Two complementary search strategies were used to identify relevant newspaper and magazine articles. First, a search using the Eureka database, specialized in print media, was performed in English and in French using the main following keywords: "covid OR coronavirus" and "management (management OR gestion in French) OR business OR SME* (PME in French) OR leadership OR manager* (dirigeant* OR gestionnaire* OR directeur* in French) OR CEO* (PDG in French) OR employee* (employé* in French)". Second, a search using the same keywords was also performed using Google News in order to identify further relevant articles.

Relevant articles were restricted to the period from March (when the WHO declared the COVID-19 pandemic) to May 2020. The first search results on Eureka yielded 2535 potentially relevant articles. A complementary search using Google News added 172 potentially relevant articles (see Figure 1).

\subsection{Selecting Relevant Articles}

Inclusion and exclusion criteria were devised in order to help eliminate articles that were not relevant to our central research question, which was to analyze the best practices implemented in organizations to manage the COVID-19 crisis. Articles describing corporate practices implemented specifically to address the COVID-19 crisis, mainly in North American or European Union countries, but also in a global context, were included in the study. Furthermore, to be included in the study, the article had to present at least one concrete example of an action taken by a particular company and the name of that company had to be cited. In contrast, articles discussing only general economic, social, or political considerations, or exploring management opinions on issues related to COVID-19, were excluded. At the end of the selection process conducted by a member of the research 
team, 246 relevant articles were included in the study, which represented about $9 \%$ of the potentially relevant articles identified in the previous step (see Figure 1).

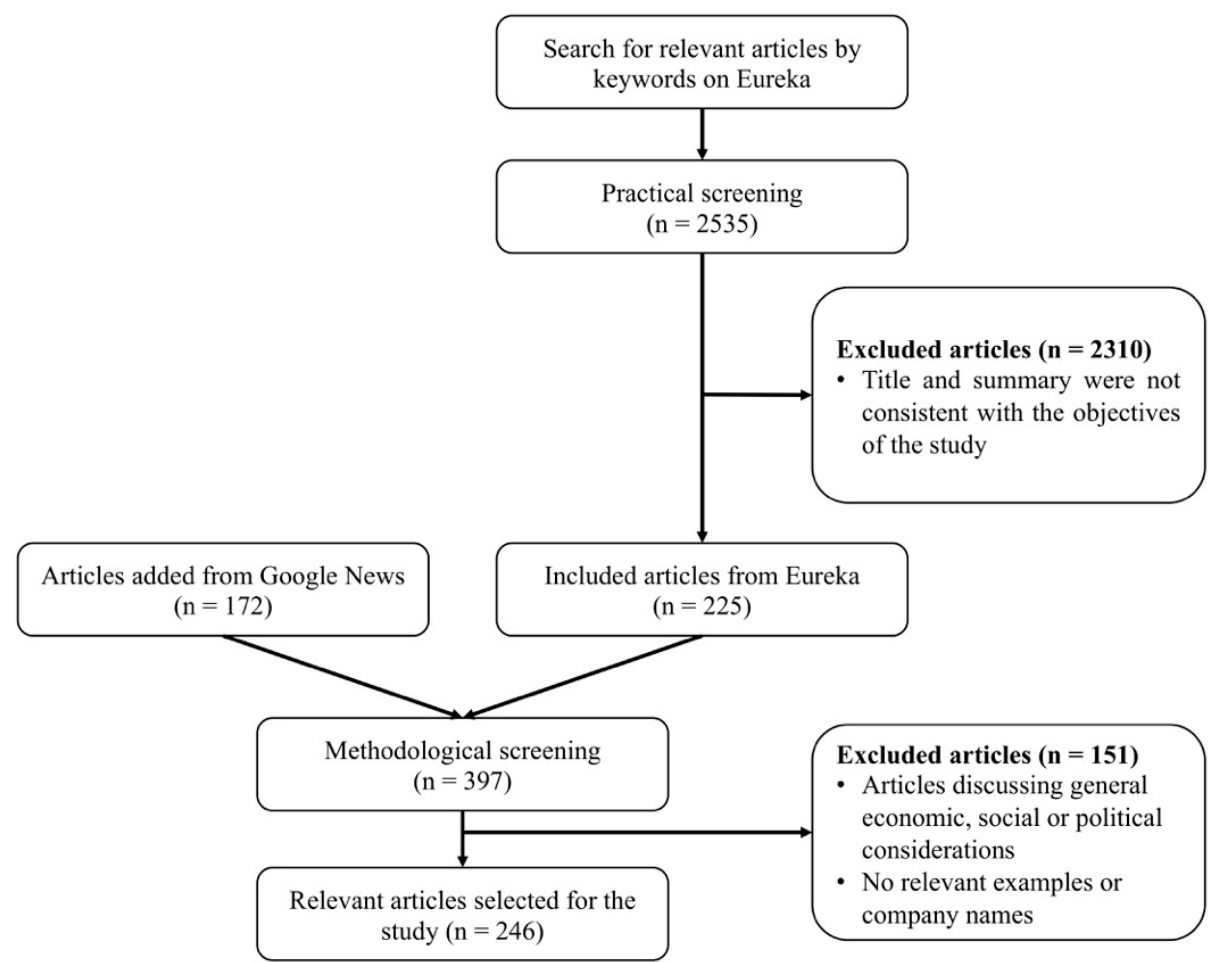

Figure 1. Selection process.

\subsection{Charting the Data}

The research team created a data extraction grid using Microsoft Excel. The sheet was divided into six main themes: design and general characteristics; positive impacts of the crisis; negative impacts of the crisis; organizational practices for managing the crisis; most valued leadership practices; and unethical behaviors. Researchers involved in the study read multiple articles in order to produce the first draft of the list of categories used in each theme. Afterwards, two coders manually coded 25 articles independently using this version of the grid (around $10 \%$ of the articles gathered). Multiple discussions occurred between the coders during this process, which helped them refine the extraction grid. At the end of this process, the first coder categorized 123 passages for the 25 articles included in the inter-coder agreement calculation. The second coder agreed on 98 of these passages, which represents an inter-coder agreement of about $80 \%$, and the categorization process was therefore deemed reliable [84]. Inconsistencies were then reconciled and all the articles were categorized manually by one of the coders.

\subsection{Collating, Summarizing, and Reporting the Results}

Data collected from the six main themes mentioned previously were analyzed and the categories created for each theme were grouped strategically for presentation purposes. Multiple figures and tables were generated to present the main findings of the study in the next sections. The percentage of articles under each theme and mentioning a particular item were also calculated; this information is presented in the figures and tables. The items deriving from a particular theme are not mutually exclusive and some articles could have been categorized under multiple items, meaning that percentages expressed in the tables are expected to add up to more than $100 \%$. 


\section{Results}

\subsection{Mapping of the Business Articles on the COVID-19 Management}

The mapping of the selected articles provides an overview of the publications on the subject, in particular regarding the sectors and regions covered, the objectives of the articles, and the focus on certain themes, in particular corporate sustainability.

Activity sectors were derived by combining multiple governmental lists from North America and Europe to obtain a comprehensive list of 26 activity sectors, which were further combined into nine main activity sectors for presentation purposes. The analysis of the sectors covered by the articles shows the great diversity of activities and companies that have been involved in managing the COVID-19 crisis (see Table 1). Some articles mentioned multiple companies in more than one sector. The analysis also illustrates the scale of this crisis, which has an impact on all sectors of activity. However, some of the sectors most affected by the pandemic were mentioned more frequently. This is particularly the case for individual and business services ( $43 \%$ of articles), transportation ( $24 \%$ ), communication $(22 \%)$, and agriculture and food $(21 \%)$, which have been particularly affected by shutdown measures and have had to adapt quickly, in particular by setting up telework, online sales, and delivery services.

Table 1. Activity sectors of the companies cited in the articles studied.

\begin{tabular}{ccc}
\hline Activity Sectors & Number of Articles & Percentage of Total Articles (\%) \\
\hline Individual and business services & 105 & 43 \\
Transportation & 60 & 24 \\
Communication & 53 & 22 \\
Agriculture and food & 51 & 15 \\
Resource extraction and materials processing & 36 & 12 \\
Textile and clothing & 30 & 8 \\
Leisure activities & 19 & 4 \\
Medical and pharmaceutical industry & 10 & 2 \\
\hline
\end{tabular}

The regions covered by the articles (see Figure 2) were mainly North America (38\%) and Europe (28\%). This concentration of coverage on certain regions was mainly due to the inclusion and exclusion criteria for the articles, particularly with regard to the languages (i.e., English and French). However, about one-third of the articles had an international perspective and focused on measures implemented in various countries or at the global level by large companies.

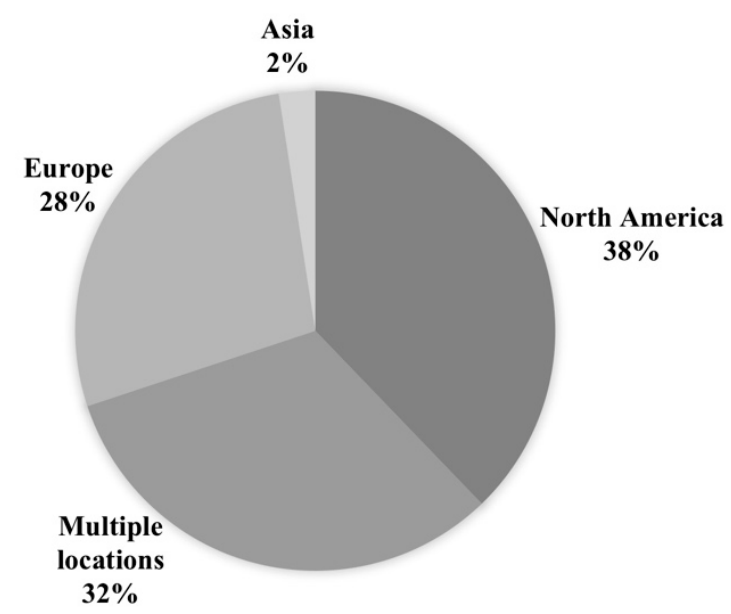

Figure 2. Geographical distribution of the companies cited in the articles. 
The analysis of the main objectives of the articles studied highlights their foci and also some issues closely related to the management of the pandemic (see Figure 3). The implications of the crisis in terms of corporate social responsibility and sustainability management were the most frequently mentioned and represented the main objective of $29 \%$ of the articles. More specifically, about two-thirds of the articles directly analyzed, or indirectly mentioned, the implications of the pandemic in terms of corporate social responsibility (CSR) or corporate sustainability (e.g., the need to strengthen the social responsibility of organizations, to review sustainable development policies, to be more responsive to stakeholders, to prioritize employee health over short-term economic objectives, etc.), even if these implications were not necessarily the main objective of the documents. While all the articles mentioned one or more example of how organizations are dealing with the pandemic, the main objective of almost a quarter of the articles was to identify and share good practices. These good practices are detailed below and cover many dimensions, including good governance, compensation, work reorganization, and various measures to help businesses managing COVID-19. About 23\% of the articles focused on the difficulties encountered by companies in managing the crisis. The rest of the articles were essentially focused on the economic challenges of the pandemic, including exploiting the opportunities related to the crisis and preparing for or managing business resumption (see Figure 3).

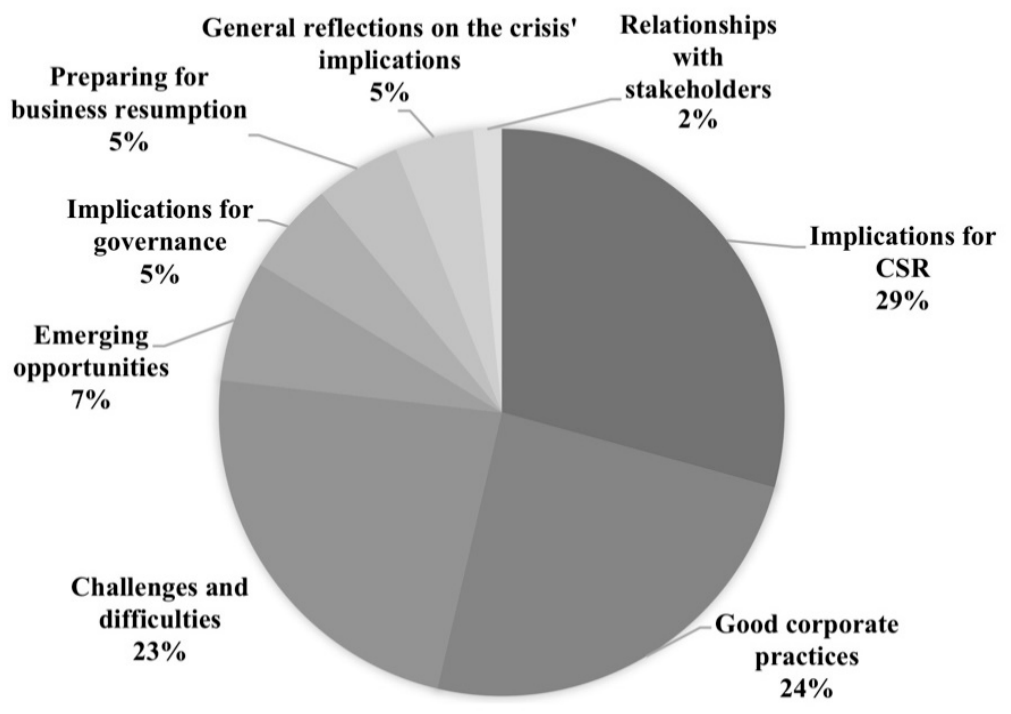

Figure 3. Main objectives of the articles.

\subsection{Opportunities and Threats of the Pandemic}

Pandemic management practices are often contextualized in relation to the opportunities and threats arising from the crisis. While the negative economic impacts of the pandemic have been widely covered in the news, the crisis has also resulted in some positive effects for many organizations. Approximately $31 \%$ of all articles (76 out of 246) analyzed highlighted these positive effects and provided various examples of how companies can benefit from them (see Table 2). Unsurprisingly, the economic opportunities arising from the crisis were mentioned in 56 articles. The emergence of new markets and the need for companies to be responsive to changes in consumer needs and habits were illustrated by various examples, such as the development of e-commerce, increased demand for organic and local products, and the growth of delivery services, among others. The importance of businesses' ability to turn a threat into an opportunity was often stressed. This capacity was illustrated by various examples, such as that of certain fitness companies that have managed to significantly increase their revenue by developing app-based and online classes in order to take advantage of the restrictions affecting a large part of the population. Similarly, 18 articles underlined job creation and other positive effects (e.g., increased profits, improved productivity of organizations) that result in particular from the 
growth of certain markets during shutdown episodes. For example, companies involved in the home delivery of meals were frequently mentioned, including recruitment announcements for 30,000 jobs at Pizza Hut, 20,000 jobs at Papa John's, 10,000 jobs at Chipotle Mexican Grill, and so forth. Security services, such as Securitas, have also announced the creation of thousands of jobs to respond to the safety concerns of many Americans in times of economic and social instability. Job creation announcements by some major essential retail chains, such as Walmart $(150,000$ hires), CVS $(50,000)$, and Dollar General $(50,000)$, show that some companies have been less affected than others by the crisis, even if the jobs announced are most often precarious and poorly paid. Some articles highlighting positive effects mentioned issues related to sustainable development, in particular many corporate leaders' awareness of the importance of paying more attention to their employees' physical health and mental well-being (mentioned in eight articles) and the reduction of air pollution (two articles). According to seven articles, the pandemic has significantly increased corporate ESG commitment. Among other things, socially responsible investments (SRIs) were reported to have been more resilient than others in times of crisis, and a growing number of investors are taking into account sustainable development issues, particularly social issues (e.g., health, stakeholder expectations, community commitments), which tends to favor organizations that have made substantial commitments in this area.

Table 2. Positive impacts of the crisis for companies.

\begin{tabular}{ccc}
\hline Positive Impacts of the Crisis & $\begin{array}{c}\text { Number of Articles for This } \\
\text { Theme }\end{array}$ & $\begin{array}{c}\text { Percentage of the Articles for This } \\
\text { Theme (\%) }\end{array}$ \\
\hline Crisis always presents opportunities & 56 & 74 \\
Increased opportunities for growth and recruitment & 18 & 24 \\
Health is becoming a priority & 8 & 11 \\
Increased commitment to ESG issues & 7 & 9 \\
Reduction of air pollution & 2 & 3 \\
Total number of articles for this theme & $\mathbf{7 6}$ & $\mathbf{1 0 0}$ \\
\hline
\end{tabular}

The threats and negative impacts of the pandemic were mentioned in proportions quite similar to those of the positive impacts ( $22 \%$ of the articles analyzed; 54 out of 246 ). The description of these negative impacts (see Table 3 ) is useful for putting into context the practices implemented by businesses to try to cope with them. Not surprisingly, the most frequently mentioned negative impacts included layoffs (temporary or permanent) and voluntary departures that were made during the pandemic. Layoffs, mentioned in 30 articles, concern most business sectors, particularly those where social distancing is more difficult to apply, such as non-essential retail (layoffs of 85,000 employees at Kohl's, the majority of the 125,000 employees at Macy's, and 14,000 employees at Urban Outfitters), transportation (layoffs of 20,000 employees at Air Canada and 2600 employees at GE Aviation), and entertainment (layoffs of 26,000 employees at AMC Theatres and 2600 employees at Cirque du Soleil). Logistical problems, particularly supply chain disruption and product wastage, were mentioned in 16 articles. Most sectors seem to be concerned by the shutdown of suppliers or the sudden imbalance between supply and demand for certain products. This imbalance has led to a significant waste of certain commodities. For example, during the shutdown, Dairy Farmers of America, one of the main American dairy cooperatives, destroyed almost 14 million liters of milk per day due to the closure of canteens and restaurants which accounted for a significant part of its sales. Nine articles also mentioned wage reduction measures that had to be put in place to respond to the economic pressures caused by the crisis. Labor shortages due to rapidly increasing absenteeism or sales growth in certain sectors were mentioned in seven articles. Absenteeism at Amazon's warehouses was reported to have reached nearly $30 \%$, even though the company was experiencing a very rapid increase in orders. Border closures also caused a shortage of seasonal workers, especially in the agricultural sector. Four articles also mentioned voluntary employee de- 
partures. Lastly, three articles mentioned the saturation of online communication networks and its negative consequences, including the speed of data transmission.

Table 3. Negative impacts of the crisis for companies.

\begin{tabular}{ccc}
\hline Negative Impacts of the Crisis & Number of Articles for This Theme & $\begin{array}{c}\text { Percentage of the Articles for This } \\
\text { Theme (\%) }\end{array}$ \\
\hline Layoffs & 30 & 56 \\
Supply chain disruption and wastage & 16 & 30 \\
Wage reductions & 9 & 17 \\
Labor shortages and absenteeism & 7 & 73 \\
Voluntary departures & 3 & 6 \\
Communication network saturation & $\mathbf{5 4}$ & $\mathbf{1 0 0}$ \\
Total number of articles for this theme & 3 & \\
\hline
\end{tabular}

\subsection{Organizational Practices for Managing the COVID-19 Crisis}

The diversity of organizational practices put in place to manage the pandemic shows the global and multifaceted nature of this crisis, which affects all organizational activities. Overall, $86 \%$ of the articles studied ( 211 out of 246 ) mentioned at least one organizational practice put in place to manage the COVID-19 pandemic. The most frequently mentioned measures can be grouped into five main themes (see Table 4): HRM, organizations' social and environmental responsibility, the reorganization of operations, the management of health aspects, and specific crisis management measures. These themes are not mutually exclusive but rather complementary and interlinked.

Table 4. Organizational practices for managing the COVID-19.

\begin{tabular}{ccc}
\hline Organizational Practices for Managing the Crisis & $\begin{array}{c}\text { Number of Articles for This } \\
\text { Theme }\end{array}$ & $\begin{array}{c}\text { Percentage of the Articles for This } \\
\text { Theme (\%) }\end{array}$ \\
\hline HRM & 105 & 50 \\
Corporate social and environmental responsibility & 85 & 40 \\
Reorganizing operations & 82 & 39 \\
Managing health aspects & 63 & 30 \\
Specific crisis management measures & $\mathbf{2 1 1}$ & 28 \\
Total number of articles for this theme & $\mathbf{1 0 0}$ \\
\hline
\end{tabular}

HRM measures were mentioned in 105 articles and encompassed a wide variety of initiatives. The most frequently cited measures concerned compensation-in particular salary maintenance for employees temporarily laid off-or, in contrast, salary reduction to cope with the crisis and avoid or limit layoffs. For example, Emirates announced a $25 \%$ to $50 \%$ salary reduction for most of its employees for a three-month period. This type of measure has been announced by many airlines, but these companies have also carried out massive layoffs. Some companies have also announced special bonuses for employees who were most exposed or had extra expenses during the shutdown. This is the case with Facebook, which has implemented a $\$ 1000$ bonus for its regular employees to compensate for the additional expenses associated with shutdown and working from home. Various measures to assist laid-off employees have also been put in place. For example, the recruitment campaigns of some companies, such as Amazon, targeted employees of other companies who lost their jobs during the pandemic. This helps to meet a temporary need for labor with employees who are expected to return to their jobs after the crisis. Similarly, some companies, such as Uber, directly contacted companies that had announced hiring during the pandemic and set up various services to support laid-off employees, including the creation of a special application (Work Hub) to group together job offers in certain regions. Conversion of these employees to other growing businesses, such as Uber Eats, has also been encouraged. The importance of communication and support 
for employees during the crisis was also stressed in many articles covering HRM issues. For example, the insurance group Macif has put in place various measures in this area, including an employee assistance and psychological support unit and a special internal phone number to answer questions about the pandemic. Lastly, companies have also developed ad hoc training programs to prepare for work during the pandemic or to better manage it, particularly in high-risk activities. This is the case, for example, of the ORPEA Group, which manages many retirement homes internationally and has implemented this type of program for its establishments' staff in collaboration with doctors and nurses.

Practices related to organizations' social and environmental responsibility were addressed in 85 articles. First, many companies have set up support schemes for collateral victims of the pandemic or for organizations involved in the fight against COVID-19. In most of the examples listed, the donations made were related to the company's main activity. For example, Danone North America and Vita Coco have donated more than \$1 million to food banks and organizations fighting malnutrition, which are particularly in demand due to the explosion in unemployment. Uber provided 10 million free trips for the elderly and medical staff during the pandemic. Similarly, Subway offered two million meals to Food Banks Canada, and the French railway company SNCF offered free train travel for medical and paramedical staff. Also, 23 articles mentioned the importance of better integrating the 17 United Nations Sustainable Development Goals and of refocusing company values to demonstrate greater corporate citizenship or a better balance between the interests of shareholders and stakeholders. Several articles also pointed out that the companies most committed to sustainable development were better prepared than others to manage the pandemic. This is the case, for example, of Patagonia, which long ago refocused its mission on social and environmental responsibility. According to its leaders, the company's B Corp certification implies considering the interests of stakeholders (in particular the community, workers, and the environment) on an equal footing with those of shareholders. However, this type of striking example was quite rare in the articles studied, and in most cases the rebalancing in favor of stakeholder interests was limited to a reduction or modification of the company's usual activities, to a greater or lesser degree, to take into account certain pressures related to the pandemic. For example, as a result of pressure from various stakeholders, Netflix and YouTube have committed to reducing the quality of online streaming to avoid saturating communication networks, which have been particularly overburdened due in part to the widespread use of teleworking platforms. Other corporate citizenship initiatives focus on communicating transparent information to stakeholders regarding the company's actual situation during the pandemic, educating customers and the public about COVID-19, and combating the proliferation of "fake news". For example, the main organizations involved in social media (e.g., Facebook, Instagram, Twitter, Google) have announced various measures to better inform users and fight against false rumors: the removal of hundreds of thousands of instances of erroneous content, the dissemination of educational messages on disease prevention to all users, and donations to government agencies to finance the large-scale communication of scientific information on COVID-19.

Examples of measures related to operations management and work organization were mentioned in 82 articles. Thirty-three articles discussed the conversion of certain activities to meet the "war effort" required during the pandemic. Most of the examples mentioned concerned the production of new essential equipment or products for which there was a severe shortage during the pandemic, such as masks, hand sanitizer, respirators, and other health-related equipment (gloves, beds, screening tests). For example, LVMH converted part of its factories to produce hand sanitizer; Apple designed and produced millions of masks for hospital staff; Ford, PSA, Air Liquide, and Tesla manufactured respirators; and the hockey equipment manufacturer Bauer produced protective visors for healthcare workers. Examples concerning the promotion of teleworking, the strengthening of companies' digitalization, and the use of videoconferencing and online collaboration software (e.g., Zoom, Microsoft Teams, Tamashare, Skype for Business, etc.) were cited 
in 38 articles. For instance, Twitter introduced in early March an allocation of \$1000 for employees voluntarily working from home. In turn, Essilor guaranteed the same Internet connection via VPN to their employees working on-site and from home. The generalization of teleworking, where possible, has led some companies to consider the longer-term sustainability of this mode of operation. For example, Bank of Montreal executives estimated that nearly 36,000 employees (about $80 \%$ of its staff) could continue to work remotely on a regular basis. Work reorganization initiatives for activities that cannot be done remotely were covered in 31 articles. These initiatives varied widely depending on the type of activity: reduction of store opening hours to allow cleaning of public spaces, division of shifts and alternating work in offices to limit the risk of contamination, restriction or elimination of business travel, and more. Reorganization has sometimes led to a radical change in business models. For example, after losing $100 \%$ of its customer base, FoodRelay, a Canadian start-up specializing in delivering meals tailored to the needs of individual employees to workplaces, reorganized its operations to make home deliveries to employees who now work from home for the most part. Furthermore, initiatives to adapt logistics and transportation activities were mentioned in 22 articles. The majority of the examples cited relate to diversifying suppliers, promoting local purchasing, and increasing stocks of strategic products to limit the risk of supply chain disruptions. For example, the major French supermarket chains have implemented various measures in collaboration with the country's main agricultural union (FNSEA) to promote "food patriotism" and sustainable development through a drastic reduction in imported products and the refocusing of food sales on local products.

Surprisingly, practices related to specific health measures were only mentioned in 63 articles. Most of these measures (e.g., social distancing, distribution of protective masks, cleaning of work areas, prohibition of external visitors) reflected the basic guidelines and recommendations of various public health organizations. However, the shortage of equipment and supplies during the shutdown period (masks, disinfectants) and the need to respond to a rapid increase in demand in some sectors have led to innovative practices to deal with the crisis. For example, several articles mention Amazon's creation of a special team bringing together various skills (procurement specialists, engineers, scientists, computer specialists) to gather medical equipment and quickly set up an internal laboratory to rapidly test the company's American employees. According to the group's leaders, this initiative has helped to reassure employees and limit the risk of COVID-19 transmission, particularly by asymptomatic individuals. Similarly, the Essilor group used the WeChat application to rapidly develop a system for tracking at-risk employees in order to locate them, monitor their journeys, and manage the quarantine of some of the staff.

Lastly, specific crisis management measures were mentioned in 60 articles. These measures were mainly aimed at the company's senior management and essentially concerned three types of decisions: setting up a crisis unit, analyzing the situation and planning a response tailored to the scale of the crisis, and restructuring activities. Nineteen articles discussed setting up a crisis unit bringing together the main leaders, representatives of the company functions most affected by the crisis and external experts. This crisis unit provides a more global view of the situation and gives more legitimacy to the decisions taken. Some companies, such as Standard Industries, have also set up a committee made up of external experts from the business, scientific, medical, and government communities to help the organization make more informed decisions. The planning measures put in place essentially revolve around developing various scenarios for how the situation could evolve, conducting risk analysis, and implementing various crisis management plans designed for each situation. These plans may be global or focus on specific issues, such as organizing voluntary departures, exploiting new opportunities, gathering information on investments, communicating with stakeholders, training front-line staff, or preparing for business resumption. While these measures were frequently mentioned in the articles analyzed, the examples were not very developed and were limited to quoting corporate leaders or mentioning the names of certain companies. However, the examples looking 
at the restructuring of companies' activities were more detailed. The majority of these examples stressed the importance of acting quickly to reduce costs and refocus companies' activities on their core business or, if necessary, to adapt businesses to the new needs resulting from the pandemic. Not surprisingly, SMEs appear to be more flexible in making these rapid and major changes. For example, following measures to reduce or halt restaurant activity, several restaurant owners in the San Francisco area have radically transformed their businesses into neighborhood grocery stores in response to the growing popularity of local trade in basic necessities and the closure of large shopping centers during the pandemic.

\subsection{Exemplifying Responsible Leadership and Preventing Unethical Behaviors}

The examples mentioned in the articles studied were not limited to good practices. They also covered the discretionary adoption of behaviors or approaches considered responsible or ethical on the part of leaders who tended to be presented as models to be emulated. These were mentioned in $24 \%$ of the articles. Conversely, $18 \%$ of the articles studied mentioned behaviors that were considered unethical and should be avoided. Attitudes and behaviors considered responsible revolved around four interrelated themes (see Table 5). One of the most often mentioned virtuous approaches (41 articles) concerned the demonstration of personal behavior considered exemplary on the part of the corporate leader, particularly in terms of their remuneration. Most of the articles in this category mentioned the need for executives to demonstrate solidarity, especially towards those who are most at risk and who are most often paid much less than their superiors. Examples of commitments by executives to forego all or part of their salary were mentioned in this category: reducing the salaries of Sodexo executives in order to finance a $\$ 30$ million fund for laid-off employees, reducing the Disney CEO's salary by $50 \%$, cancelling the salary of the Marriott Hotels CEO and reducing the salary of the company's top executives by half, cancelling the salary of Boeing's CEO, limiting the salary of Columbia Sportswear's CEO to $\$ 10,000$, and so on. Another frequently mentioned approach (21 articles) concerned listening to stakeholders, especially employees, and encouraging them to express themselves internally about the crisis. For example, the CEO of the pharmaceutical group Unither stated that he spends most of his days on the phone speaking with various stakeholders about the crisis and its implications. This listening approach is often associated with a benevolent and empathetic attitude on the part of management with regard to the impacts of the pandemic. Some articles mentioned the need to recognize employees' efforts, to demonstrate that their health is a priority issue for the company, and to return to more essential human values. In addition to its ethical aspects, such an approach appears to be important for retaining and motivating employees in the longer term. The importance of delegating, taking a step back, and not overreacting to the crisis was also mentioned. As the CEO of Accenture sums up: "My job as a leader is not to put more stress into a system that is already stressed" [85]. Lastly, two articles mentioned the need for long-term focus, emotional maturity, and reassuring of employees by avoiding overly pessimistic or optimistic comments about the pandemic. According to a consultant specializing in leadership skills, "it takes a great deal of consciousness from leaders in the midst of crisis and upheaval to maintain a balance that is neither too negative nor overly optimistic" [86].

Table 5. Responsible leadership in the midst of the crisis.

\begin{tabular}{ccc}
\hline Responsible Leadership Measures & Number of Articles for This Theme & $\begin{array}{c}\text { Percentage of the Articles for This } \\
\text { Theme (\%) }\end{array}$ \\
\hline Leaders' exemplary personal behavior & 41 & 69 \\
Communication with stakeholders & 21 & 36 \\
Behavioral measures & 2 & 3 \\
Total number of articles for this theme & $\mathbf{5 9}$ & $\mathbf{1 0 0}$ \\
\hline
\end{tabular}


The examples of behaviors that were considered unethical and should be proscribed revolved around three main types of approaches (see Table 6). The first type of approach, which was criticized in 29 articles, was the inadequacy of measures put in place by some companies to protect the most at-risk employees and customers. Interestingly, several companies, such as Amazon and Uber, which were often cited for their exemplary initiatives, were also often criticized for not doing enough. For example, some Amazon employees said that many people who tested positive for COVID-19 continued to work in the company's warehouses or in the delivery of goods. Similar accusations have been made against other companies involved in transportation or consumer sales, such as Whole Foods, Walmart, Instacart, and FedEx. Some companies, such as BuzzFeed or Amazon, have stopped all or part of their operations in some warehouses, not because of government-imposed shutdown measures, but because of internal pressure from employees refusing to take health risks for the benefit of the company. The second type of approach, which was criticized in 13 articles, was the opportunism of some companies that have tried to take undue advantage of the crisis. Among other things, the articles cited abusive or even fraudulent behavior aimed at taking advantage of the aid put in place by governments, the controversial role of certain lobbyists during the crisis period to promote activities with high environmental impacts (large-scale production of plastic packaging, relaunch of certain oil projects), the pressure exerted on suppliers weakened by the crisis (late payments, abusive credit rates), or the misleading statements made by certain corporate leaders. For example, the commitment of the CEO of United Airlines to waive his base salary appears misleading as this salary represents less than $10 \%$ of his total compensation, which is largely composed of bonuses and stock options. The third type of unethical approach, which was criticized in six articles, concerned companies' denial of reality in the face of the pandemic and their lack of consideration for their most vulnerable employees during the crisis. For example, statements by Tesla's CEO about "excessive panic" over the pandemic and his pressure to keep its California plants operating during general shutdown have been criticized. Likewise, the articles denounced the insufficient salary of employees working in Amazon's warehouses and the company's threats to suspend the remuneration of French employees who wanted to avail themselves of their "right of withdrawal" (guaranteed by the French labor code) in order not to expose themselves to excessive risks during the pandemic.

Table 6. Unethical behaviors during the pandemic.

\begin{tabular}{ccc}
\hline Unethical Behaviors & Number of Articles for This Theme & $\begin{array}{c}\text { Percentage of the Articles for This } \\
\text { Theme (\%) }\end{array}$ \\
\hline Failure to adequately protect employees & 29 & $66 \%$ \\
Opportunism & 13 & $30 \%$ \\
Denial of the seriousness of the crisis & 6 & $14 \%$ \\
Total number of articles for this theme & $\mathbf{4 4}$ & $\mathbf{1 0 0 \%}$ \\
\hline
\end{tabular}

\section{Discussion}

The objective of this study was to analyze the early COVID-19 crisis management practices implemented in organizations based on a scoping review of relevant business articles published on this issue in newspapers and magazines between March and May 2020. The analysis of the 246 articles identified in the study provides a global view of the main initiatives in this field and the challenges faced by companies in this new and unusual situation which, more often than not, calls into question the possibility of "business as usual" and may even threaten companies' survival.

The article makes important contributions to the emerging literature on organizations' pandemic management. First, it represents, to our knowledge, the first systematic study of the measures put in place, in practical terms, by companies during the pandemic based on a large number of concrete examples. The current literature on the subject is based on a health perspective rather than a managerial one (e.g., $[65-67,69,71])$, and studies focusing 
specifically on business are still rare. These studies focus, for the most part, on specific sectors such as universities, slaughterhouses, or the banking sector [20,38,59]. Moreover, the research published to date does not focus on the practices actually implemented by organizations, but on related themes, such as proactive and less proactive response strategies, the level of corporate resilience, or the development of telework $[1,37,40-46]$.

Second, the study contributes to the literature on corporate sustainability. Although this literature is now vast and diverse, health issues have clearly been overlooked [21-24]. An interesting result of the study is to show that about two-thirds of the news articles mentioned the implications of the crisis in terms of sustainable development or corporate social responsibility. This result tends to confirm that the COVID-19 pandemic represents, in a broad sense, a sustainable development crisis that raises many social, economic, and environmental issues. This study therefore helps to show the importance, for corporate leaders and researchers alike, of better integrating health issues into corporate sustainability practices. In addition, it contributes to debates in the literature on the sometimes symbolic response of organizations to external pressures and on the lack of commensurability of corporate sustainability achievements [87-89]. This observation tends to confirm the relevance of the legitimacy theory for analyzing corporate sustainability [90-92]. According to this theory, sustainability practices are primarily motivated by organizations' concern for social legitimacy and by the external pressures they are subject to because of their impacts. For example, the criticisms concerning Amazon employees' exposure to COVID-19 certainly motivated the company to create a laboratory for testing employees. A similar series of events appears to have occurred with Uber, whose initiatives to promote the retraining of laid-off employees were certainly linked to the criticisms that the company has been subjected to regarding the precariousness of drivers' employment, particularly in times of crisis. These examples also raise more fundamental questions about the complexity of assessing organizations' sustainability performance. Indeed, as illustrated by the diversity of the examples identified, the assessment of such performance can be based on heterogeneous and non-commensurable indicators that are difficult to compare between companies and that can lead to contradictory or erroneous assessments [87,89,93]. Among other things, initiatives judged to be virtuous according to some criteria do not necessarily compensate for poor performance according to other indicators, even assuming that the available information is reliable. Depending on the examples or indicators considered, one may therefore come to a very different judgement on whether a given organization is making either a substantial or only symbolic commitment to socially responsible behavior in the context of the pandemic or other sustainability issues.

Third, this study also makes a methodological contribution. Research based on scoping reviews remains underdeveloped in the field of management, in contrast to other disciplines where this approach is commonly used. Moreover, to our knowledge, no other study has been conducted using a scoping review of current business articles on organizational practices, let alone on pandemic management. Despite its current under-use, this methodology appears particularly relevant for analyzing current issues for which there are still few or no scientific or in-depth studies, and which require rapid responses from organizations. This scoping review's focus on news articles rather than on the (almost nonexistent) academic management literature provides access to a large amount of relevant information, published very recently, which would have taken a considerable amount of time to collect through empirical studies based on more traditional approaches (case studies, interviews with managers, quantitative surveys). Moreover, the methodology used allows for a focus on practical examples from many different sources rather than on perceptions or secondary data based on a single study. 


\section{Conclusions}

The conclusions and implications of this research need to be nuanced, in particular due to methodological limitations. Even if the examples mentioned were often corroborated by several different sources, media reporting may not involve the same level of rigor as scholarly studies. Moreover, despite the rigorous inclusion and exclusion criteria used, the cases presented were often not very detailed and raise many questions that remain unanswered concerning companies' real motivations, the beneficial and harmful effects of certain practices, and the context in which the measures described were implemented. The majority of these examples relate to large companies, whose practices are more visible and better documented than those of SMEs. The inclusion and exclusion criteria used in this scoping review did not allow for an analysis of initiatives implemented in other regions of the world, particularly in Asian countries that were the first to be affected by the pandemic. Lastly, the focus of this study being individual organizations, it did not allow for studying how COVID-19 management measures, such as physical distancing, were applied to multi-story buildings with limited elevator capacity. It should be noted, however, that the above-mentioned limitations may also apply to a large part of the studies based on more traditional methods, which generally give contingent results that need to be put into perspective and whose data (collected by means of interviews, questionnaires, etc.), when taken individually, present significant biases. It is reasonable to assume that, in the relatively near future, the empirical literature on COVID-19 management will be much more extensive. This literature will certainly make it possible to deepen avenues of research still unexplored (e.g., strategies and practices implemented in SMEs, comparative analysis of measures adopted in different countries, including Asian countries, detailed case studies) and to draw more comprehensive conclusions on how this crisis was managed in various types of organizations. Scoping or systematic reviews of the academic literature will then be a relevant approach for synthesizing knowledge on organizational practices for managing the pandemic.

This study has very important managerial implications. Indeed, many corporate leaders are confused about how to appropriately manage the current crisis and what practices should be adopted. The lack of in-depth research on the subject and the highly fragmented nature of information sources on COVID-19 management in organizations mean that decision-makers have little access to useful information that could inform their reflections on the most relevant responses to adopt. Taken individually, the articles used in this study are obviously of little significance. However, the analysis of a large number of articles describing examples of good practices, approaches to be favored, or behaviors to be avoided allows a global vision of the possible solution avenues in different organizations. While some practices are very contingent and difficult to generalize, others may certainly be more inspiring for corporate leaders who are interested in learning from the measures implemented by other organizations. In addition, the uncertainties about the pandemic's implications and the possible occurrence of new waves of contamination should prompt leaders to plan measures that could be adopted in the event of future outbreaks. In this context, this article offers a wide range of measures that, while they may seem of little or no relevance to a company today, could become very relevant in the future.

Author Contributions: Conceptualization, O.B. and L.G.; methodology, O.B. and L.G.; validation, M.-C.B., L.R. and L.G.; formal analysis, M.-C.B. and L.R.; investigation, O.B., M.-C.B. and L.R.; resources, O.B. and L.G.; writing-original draft preparation, O.B. and M.-C.B.; writing-review and editing, O.B., M.-C.B., L.R. and L.G.; visualization, M.-C.B.; supervision, O.B., M.-C.B. and L.G.; project administration, O.B. and L.G.; funding acquisition, O.B. All authors have read and agreed to the published version of the manuscript.

Funding: This research was funded by the Canada Research Chair in Internalization of Sustainability Practices and Organizational Accountability.

Institutional Review Board Statement: Not applicable. 
Informed Consent Statement: Not applicable.

Data Availability Statement: Not applicable.

Conflicts of Interest: The authors declare no conflict of interest.

\section{References}

1. Bapuji, H.; de Bakker, F.G.; Brown, J.A.; Higgins, C.; Rehbein, K.; Spicer, A. Business and Society research in times of the corona crisis. Bus. Soc. 2020, 59, 1067-1078. [CrossRef]

2. McKee, M.; Stuckler, D. If the world fails to protect the economy, COVID-19 will damage health not just now but also in the future. Nat. Med. 2020, 26, 640-642. [CrossRef]

3. Bansal, T. Behavioral finance and COVID-19: Cognitive errors that determine the financial future. SSRN 2020. [CrossRef]

4. Ceylan, R.F.; Ozkan, B.; Mulazimogullari, E. Historical evidence for economic effects of COVID-19. Eur. J. Health Econ. 2020, 21, 817-823. [CrossRef] [PubMed]

5. Bryce, C.; Ring, P.; Ashby, S.; Wardman, J. Resilience in the face of uncertainty: Early lessons from the COVID-19 pandemic. J. Risk Res. 2020, 23, 880-887. [CrossRef]

6. Oehmen, J.; Locatelli, G.; Wied, M.; Willumsen, P. Risk, uncertainty, ignorance and myopia: Their managerial implications for B2B firms. Ind. Mark. Manag. 2020, 88, 330-338. [CrossRef]

7. Carnevale, J.B.; Hatak, I. Employee adjustment and well-being in the era of COVID-19: Implications for human resource management. J. Bus. Res. 2020, 116, 183-187. [CrossRef] [PubMed]

8. Winters, N.; Langer, L.; Geniets, A. Scoping review assessing the evidence used to support the adoption of mobile health (mHealth) technologies for the education and training of community health workers (CHWs) in low-income and middle-income countries. BMJ Open 2018, 8, e019827. [CrossRef]

9. Mueller, M.; D’Addario, M.; Egger, M.; Cevallos, M.; Dekkers, O.; Mugglin, C.; Scott, P. Methods to systematically review and meta-analyse observational studies: A systematic scoping review of recommendations. BMC Med. Res. Methodol. 2018, 18, 44. [CrossRef]

10. Colquhoun, H.L.; Levac, D.; O’Brien, K.K.; Straus, S.; Tricco, A.C.; Perrier, L.; Kastner, M.; Moher, D. Scoping reviews: Time for clarity in definition, methods, and reporting. J. Clin. Epidemiol. 2014, 67, 1291-1294. [CrossRef]

11. Wong, E.; Ho, K.; Wong, S.; Cheung, A.; Yeoh, E. Workplace safety and coronavirus disease (COVID-19) pandemic: Survey of employees. Bull. World Health Organ. 2020. [CrossRef]

12. Koh, D. Occupational risks for COVID-19 infection. Occup. Med. 2020, 70, 3-5. [CrossRef]

13. World Health Organization. Getting Your Workplace Ready for COVID-19: How COVID-19 Spreads, 19 March 2020; World Health Organization: Geneva, Switzerland, 2020.

14. International Labour Organization. ILO Monitor: COVID-19 and the World of Work, 3rd ed.; ILO: Geneva, Switzerland, 2020.

15. He, H.; Harris, L. The impact of Covid-19 pandemic on corporate social responsibility and marketing philosophy. J. Bus. Res. 2020, 116, 176-182. [CrossRef] [PubMed]

16. Corbera, E.; Anguelovski, I.; Honey-Rosés, J.; Ruiz-Mallén, I. Academia in the time of COVID-19: Towards an ethics of care. Plan. Theory Pract. 2020, 21, 191-199. [CrossRef]

17. Holton, I.; Glass, J.; Price, A.D. Managing for sustainability: Findings from four company case studies in the UK precast concrete industry. J. Clean. Prod. 2010, 18, 152-160. [CrossRef]

18. Kleine, A.; Von Hauff, M. Sustainability-driven implementation of corporate social responsibility: Application of the integrative sustainability triangle. J. Bus. Ethics 2009, 85, 517-533. [CrossRef]

19. Junior, A.N.; de Oliveira, M.C.; Helleno, A.L. Sustainability evaluation model for manufacturing systems based on the correlation between triple bottom line dimensions and balanced scorecard perspectives. J. Clean. Prod. 2018, 190, 84-93. [CrossRef]

20. Talbot, D.; Ordonez-Ponce, E. Canadian banks' responses to COVID-19: A strategic positioning analysis. J. Sustain. Financ. Invest. 2020. [CrossRef]

21. Yach, D. Health as a cornerstone of good business and sustainable development. Am. J. Public Health 2016, 106, 1758-1759. [CrossRef]

22. Swerissen, H.; Crisp, B.R. The sustainability of health promotion interventions for different levels of social organization. Health Promot. Int. 2004, 19, 123-130. [CrossRef] [PubMed]

23. Redmond, M.S.; Kalina, C.M.; Strasser, P.B. A successful occupational health nurse-driven health promotion program to support corporate sustainability. Aaohn J. 2009, 57, 507-514. [CrossRef] [PubMed]

24. Fuisz-Kehrbach, S.-K. A three-dimensional framework to explore corporate sustainability activities in the mining industry: Current status and challenges ahead. Resour. Policy 2015, 46, 101-115. [CrossRef]

25. Boiral, O.; Heras-Saizarbitoria, I.; Brotherton, M.-C. Corporate sustainability and indigenous community engagement in the extractive industry. J. Clean. Prod. 2019, 235, 701-711. [CrossRef]

26. Tsalis, T.A.; Stylianou, M.S.; Nikolaou, I.E. Evaluating the quality of corporate social responsibility reports: The case of occupational health and safety disclosures. Saf. Sci. 2018, 109, 313-323. [CrossRef]

27. Fonseca, L.; Carvalho, F. The reporting of SDGs by Quality, Environmental, and Occupational Health and Safety-certified organizations. Sustainability 2019, 11, 5797. [CrossRef] 
28. Ruiz-Frutos, C.; Pinos-Mora, P.; Ortega-Moreno, M.; Gómez-Salgado, J. Do companies that claim to be socially responsible adequately manage occupational safety and health? Saf. Sci. 2019, 114, 114-121. [CrossRef]

29. Shan, C.; Tang, D.Y. The value of employee satisfaction in disastrous times: Evidence from Covid-19. SSRN 2020. [CrossRef]

30. Bansal, T. What Business Professors Are Saying about COVID-19. Network for Business Sustainability. 11 May 2020. Available online: https:/ / www.nbs.net/articles/what-business-professors-are-saying-about-covid-19 (accessed on 1 April 2021).

31. Dowell, G. Why Don't Businesses See This Coming? Organizations and the Natural Environment: A Division of AOM. 31 March 2020. Available online: https:/ / one.aom.org/covid-19-insights-from-business-sustainability-scholars/covid-19-insights-glen-dowell (accessed on 1 April 2021).

32. Rivera, J. Responding to Slow Onset Disasters: The Boiling Frog Syndrome. Organizations and the Natural Environment: A Division of AOM. 26 March 2020. Available online: https:/ / one.aom.org/covid-19-insights-from-business-sustainability-scholars/rivera (accessed on 1 April 2021).

33. Loughran, T.; McDonald, B. Management disclosure of risk factors and COVID-19. SSRN 2020. [CrossRef]

34. Hoffman, A.; Jennings, D. How We Respond to COVID-19 Foreshadows Future Life in the Anthropocene. Organizations and the Natural Environment: A Division of AOM. 26 March 2020. Available online: https:/ / one.aom.org/ covid-19-insights-from-businesssustainability-scholars/hoffman-and-jennings (accessed on 1 April 2021).

35. Oetzel, J.; Oh, C.H. How What We Know About Business Response to Disasters Relates to COVID-19. Organizations and the Natural Environment: A Division of AOM. 26 March 2020. Available online: https:/ / one.aom.org/ covid-19-insights-from-businesssustainability-scholars/oetzel-and-oh (accessed on 1 April 2021).

36. Appiah-Konadu, P.; Atanya, O. COVID-19: A Wake Up Call for Collaborative Action towards a More Sustainable Nigeria. Organizations and the Natural Environment: A Division of AOM. 7 April 2020. Available online: http://one.aom.org/covid-19 -insights-from-business-sustainability-scholars/covid-19-insights-appiah-konadu-and-atanya (accessed on 1 April 2021).

37. Hassan, T.A.; Hollander, S.; van Lent, L.; Tahoun, A. Firm-Level Exposure to Epidemic Diseases: COVID-19, SARS, and H1N1; National Bureau of Economic Research: Cambridge, MA, USA, 2020.

38. Wang, C.; Cheng, Z.; Yue, X.-G.; McAleer, M. Risk management of COVID-19 by universities in China. J. Risk Financ. Manag. 2020, 13, 36. [CrossRef]

39. Amankwah-Amoah, J. Stepping up and stepping out of COVID-19: New challenges for environmental sustainability policies in the global airline industry. J. Clean. Prod. 2020, 271, 123000. [CrossRef]

40. Solanki, S. An exploratory study on behavioral science of HR managers to respond the COVID-19 challenge. SSRN 2020. [CrossRef]

41. Semple, S.; Cherrie, J.W. COVID-19: Protecting worker health. Ann. Work Expo. Health 2020, 64, 461-464. [CrossRef]

42. Crane, A. COVID-19 and the destitution of workers in global supply chains. Organizations and the Natural Environment: A Division of AOM. 1 April 2020. Available online: http://one.aom.org/covid-19-insights-from-business-sustainability-scholars/covid-19 -insights-crane (accessed on 1 April 2021).

43. Dolsak, N.; Prakash, A. Coronavirus and Global Supply Chain Disruption: A Wake-Up Call for Climate Policy? Forbes. 7 March 2020. Available online: https://www.forbes.com/sites/prakashdolsak/2020/03/07/coronavirus-and-global-supply-chaindisruption-a-wake-up-call-for-climate-policy/?sh=2dcc88911161 (accessed on 1 April 2021).

44. Centers for Disease Control and Prevention. Interim Guidance for Businesses and Employers to Plan and Respond to Coronavirus Disease 2019 (COVID-19), February 2020; Centers for Disease Control and Prevention: Atlanta, GA, USA, 2020.

45. Belzunegui-Eraso, A.; Erro-Garcés, A. Teleworking in the Context of the Covid-19 Crisis. Sustainability 2020, 12, 3662. [CrossRef]

46. Stephany, F.; Dunn, M.; Sawyer, S.; Lehdonvirta, V. Distancing bonus or downscaling loss? The changing livelihood of US online workers in times of Covid-19. J. Econ. Soc. Geogr. 2020, 111, 561-573. [CrossRef] [PubMed]

47. Kantamneni, N. The impact of the COVID-19 pandemic on marginalized populations in the United States: A research agenda. J. Vocat. Behav. 2020, 119, 103439. [CrossRef] [PubMed]

48. Eisen, D. Employee presenteeism and occupational acquisition of COVID-19. Med. J. Aust. 2020, 213, 140. [CrossRef]

49. Berger, Z.D.; Evans, N.G.; Phelan, A.L.; Silverman, R.D. Covid-19: Control measures must be equitable and inclusive. BMJ 2020, 368, m1141. [CrossRef] [PubMed]

50. International Labour Organisation. COVID-19 Crisis and the Informal Economy: Immediate Responses and Policy Challenges; ILO: Geneva, Switzerland, 2020.

51. Hatum, A.; Pettigrew, A.; Michelini, J. Building organizational capabilities to adapt under turmoil. J. Chang. Manag. 2010, 10, 257-274. [CrossRef]

52. Teece, D.; Peteraf, M.; Leih, S. Dynamic capabilities and organizational agility: Risk, uncertainty, and strategy in the innovation economy. Calif. Manag. Rev. 2016, 58, 13-35. [CrossRef]

53. Duchek, S. Growth in the Face of Crisis: The Role of Organizational Resilience Capabilities, Academy of Management Proceedings, Briarcliff Manor, NY, 2014; Academy of Management: Briarcliff Manor, NY, USA, 2014; p. 13487.

54. Williams, T.A.; Gruber, D.A.; Sutcliffe, K.M.; Shepherd, D.A.; Zhao, E.Y. Organizational response to adversity: Fusing crisis management and resilience research streams. Acad. Manag. Ann. 2017, 11, 733-769. [CrossRef]

55. Bundy, J.; Pfarrer, M.D.; Short, C.E.; Coombs, W.T. Crises and crisis management: Integration, interpretation, and research development. J. Manag. 2017, 43, 1661-1692. [CrossRef] 
56. Gimenez, R.; Hernantes, J.; Labaka, L.; Hiltz, S.R.; Turoff, M. Improving the resilience of disaster management organizations through virtual communities of practice: A Delphi study. J. Contingencies Crisis Manag. 2017, 25, 160-170. [CrossRef]

57. Steelman, T.A.; McCaffrey, S. Best practices in risk and crisis communication: Implications for natural hazards management. Nat. Hazards 2013, 65, 683-705. [CrossRef]

58. Boldog, P.; Tekeli, T.; Vizi, Z.; Dénes, A.; Bartha, F.A.; Röst, G. Risk assessment of novel coronavirus COVID-19 outbreaks outside China. J. Clin. Med. 2020, 9, 571. [CrossRef] [PubMed]

59. Dyal, J.W.; Grant, M.P.; Broadwater, K.; Bjork, A.; Waltenburg, M.A.; Gibbins, J.D.; Hale, C.; Silver, M.; Fischer, M.; Jonathan Steinberg, M.P.H.; et al. COVID-19 among workers in meat and poultry processing facilities-19 states, April 2020. Morb. Mortal. Wkly. Rep. 2020, 69, 557-561. [CrossRef]

60. World Health Organization. Health Workers Exposure Risk Assessment and Management in the Context of COVID-19 Virus: Interim Guidance, 4 March 2020; World Health Organization: Geneva, Switzerland, 2020.

61. Burton, C.; Coles, B.; Anisesh, A.; Smith, S.; Toomey, E.; Chan, X.H.; Ross, L.; Greenhalgh, T. Performance and impact of disposable and reusable respirators for healthcare workers during pandemic respiratory disease: A rapid evidence review. Occup. Environ. Med. 2021. [CrossRef]

62. World Health Organization. Considerations for Public Health and Social Measures in the Workplace in the Context of COVID-19: Annex to Considerations in Adjusting Public Health and Social Measures in the Context of COVID-19, 10 May 2020; World Health Organization: Geneva, Switzerland, 2020.

63. Yilmazkuday, H. Stay-at-home works to fight against COVID-19: International evidence from Google mobility data. J. Hum. Behav. Soc. Environ. 2021. [CrossRef]

64. Baker, M.G. Characterizing occupations that cannot work from home: A means to identify susceptible worker groups during the COVID-19 pandemic. MedRxiv 2020. [CrossRef]

65. Craven, M.; Liu, L.; Mysore, M.; Wilson, M. COVID-19: Implications for Business; McKinsey \& Company: New York, NY, USA, 2020.

66. George, R.; George, A. Prevention of COVID-19 in the workplace. Samj S. Afr. Med. J. 2020, 110, 4. [CrossRef]

67. Vnoučková, L. Impact of COVID-19 on human resource management. Rev. Latinoam. Investig. Soc. 2020, 3, 18-21.

68. Lee, I.; Wang, C.-C.; Lin, M.-C.; Kung, C.-T.; Lan, K.-C.; Lee, C.-T. Effective strategies to prevent coronavirus disease-2019 (COVID-19) outbreak in hospital. J. Hosp. Infect. 2020, 105, 102-103. [CrossRef] [PubMed]

69. Koonin, L.M. Novel coronavirus disease (COVID-19) outbreak: Now is the time to refresh pandemic plans. J. Bus. Contin. Emerg. Plan. 2020, 13, 298-312.

70. World Health Organization. Operational Considerations for Case Management of COVID-19 in Health Facility and Community: Interim Guidance, 19 March 2020; World Health Organization: Geneva, Switzerland, 2020.

71. Marin-Garcia, J.A.; Garcia-Sabater, J.P.; Ruiz, A.; Maheut, J.; Garcia-Sabater, J. Operations Management at the service of health care management: Example of a proposal for action research to plan and schedule health resources in scenarios derived from the COVID-19 outbreak. J. Ind. Eng. Manag. 2020, 13, 213-227. [CrossRef]

72. Xiarewana, B.; Civelek, M.E. Effects of Covid-19 on China and the world economy: Birth pains of the post-digital ecosystem. J. Int. Tradelogistics Law 2020, 6, 147-157.

73. Block, S.; Kahn, S.; Rogers, B.; Sachs, B.I. How and Why to Empower Workers in the COVID-19 Response; Roosevelt Institute: New York, NY, USA, 2020.

74. Bouziri, H.; Smith, D.R.M.; Descatha, A.; Dab, W.; Jean, K. Working from home in the time of covid-19: How to best preserve occupational health? Occup. Environ. Med. 2020, 77, 509-510. [CrossRef] [PubMed]

75. Kohn, C. Managing Stress in the Workplace during COVID-19: 5 Top Tips for Employers and Employees. SAGE Momentum 2020, $3,1-2$.

76. Ramesh, N.; Siddaiah, A.; Joseph, B. Tackling corona virus disease 2019 (COVID 19) in workplaces. Indian J. Occup. Environ. Med. 2020, 24, 16-18. [PubMed]

77. Carroll, C.E.; McCombs, M. Agenda-setting effects of business news on the public's images and opinions about major corporations. Corp. Reput. Rev. 2003, 6, 36-46. [CrossRef]

78. Laskin, A.V.; Samoilenko, S.A. The investor communication strategies of newspaper corporations: A computerized content analysis. Int. J. Strateg. Commun. 2014, 8, 196-214. [CrossRef]

79. Schultz, F.; Kleinnijenhuis, J.; Oegema, D.; Utz, S.; Van Atteveldt, W. Strategic framing in the BP crisis: A semantic network analysis of associative frames. Public Relat. Rev. 2012, 38, 97-107. [CrossRef]

80. Lee, T.H.; Riffe, D. Business news framing of corporate social responsibility in the United States and the United Kingdom: Insights from the implicit and explicit CSR framework. Bus. Soc. 2019, 58, 683-711. [CrossRef]

81. Arksey, H.; O’Malley, L. Scoping studies: Towards a methodological framework. Int. J. Soc. Res. Methodol. 2005, 8, 19-32. [CrossRef]

82. Kastner, M.; Tricco, A.C.; Soobiah, C.; Lillie, E.; Perrier, L.; Horsley, T.; Welch, V.; Cogo, E.; Antony, J.; Straus, S.E. What is the most appropriate knowledge synthesis method to conduct a review? Protocol for a scoping review. BMC Med. Res. Methodol. 2012, 12, 114. [CrossRef] [PubMed]

83. Peters, M.D.; Godfrey, C.M.; Khalil, H.; McInerney, P.; Parker, D.; Soares, C.B. Guidance for conducting systematic scoping reviews. Int. J. Evid. Based Healthc. 2015, 13, 141-146. [CrossRef] [PubMed] 
84. Neuendorf, K. The Content Analysis Guidebook; Sage Publications: Thousand Oaks, CA, USA, 2002.

85. Edgecliffe-Johnson, A.; Neville, S.; Moules, J. Strong Leadership for Uncertain Times. Financial Times. 23 March 2020. Available online: https:/ / www.ft.com/content/e4aec0cc-6849-11ea-a3c9-1fe6fedcca75 (accessed on 1 April 2021).

86. Bague, H.; Cava, J.; Hopkinson, M. Applying Past Leadership Lessons to the Coronavirus Pandemic; McKinsey \& Company: New York, NY, USA, 2020.

87. Delmas, M.A.; Etzion, D.; Nairn-Birch, N. Triangulating environmental performance: What do corporate social responsibility ratings really capture? Acad. Manag. Perspect. 2013, 27, 255-267. [CrossRef]

88. Boiral, O.; Talbot, D.; Brotherton, M.C. Measuring sustainability risks: A rational myth? Bus. Strategy Environ. 2020, $29,2557-2571$. [CrossRef]

89. Escrig-Olmedo, E.; Muñoz-Torres, M.J.; Fernández-Izquierdo, M.Á.; Rivera-Lirio, J.M. Measuring corporate environmental performance: A methodology for sustainable development. Bus. Strategy Environ. 2017, 26, 142-162. [CrossRef]

90. Hummel, K.; Schlick, C. The relationship between sustainability performance and sustainability disclosure-Reconciling voluntary disclosure theory and legitimacy theory. J. Account. Public Policy 2016, 35, 455-476. [CrossRef]

91. Cho, C.H.; Laine, M.; Roberts, R.W.; Rodrigue, M. Organized hypocrisy, organizational façades, and sustainability reporting. Account. Organ. Soc. 2015, 40, 78-94. [CrossRef]

92. Boiral, O.; Heras-Saizarbitoria, I.; Brotherton, M.-C. Assessing and improving the quality of sustainability reports: The auditors' perspective. J. Bus. Ethics 2019, 155, 703-721. [CrossRef]

93. Boiral, O.; Brotherton, M.-C.; Talbot, D. Building trust in the fabric of sustainability ratings: An impression management perspective. J. Clean. Prod. 2020, 260, 120942. [CrossRef] 